\title{
Comparative growth and interference between cheatgrass and yellow starthistle seedlings
}

\author{
ROGER L. SHELEY AND LARRY L. LARSON
}

\begin{abstract}
Authors are graduate research assistant and associate professor Department of Rangeland Resources, Oregon State University, Corvallis, and are stationed at OSU-EOSC Agriculture Program, Eastern Oregon State College, La Grande 97850.
\end{abstract}

\section{Abstract}

Annual grasslands in the Pacific Northwest are being invaded by Eurasian weeds, such as yellow starthistle (Centaurea solstitialis L.). Plant-plant interactions influence community dynamics and plant establishment. The objectives of this study were to quantify the effects of interference between seedlings of cheatgrass (Bromus tectorum $\mathbf{L}$.) and yellow starthistle and to compare growth of isolated individuals of these species. Isolated individuals and addition series mixtures with total stand densities ranging from 20-20,000 plants $\mathrm{m}^{-2}$ were grown in an environmental chamber $\left(10^{\circ} \mathrm{C}, 12\right.$-hour daylength $)$. Individuals were harvested on 4-day intervals between 10 and 46 days, and mixtures were harvested 37 days after planting. Shoot weight, root weight, leaf area, and total root length of isolated individuals were similar. Yellow starthistle roots penetrated deeper into the soil than did cheatgrass roots 22 days after planting. Intraspecific interference was greater than interspecific interference for both species, and resource partitioning via rooting depth was evident. The yellow starthistle root:shoot ratio and the cheatgrass lower (below 200 $\mathrm{mm}$ ): upper (above $200 \mathrm{~mm}$ ) root ratio increased with increasing densities. Yellow starthistle and cheatgrass minimize interspecific interference as seedlings through differential growth and rooting depth. Invasion of cheatgrass rangelands by yellow starthistle increase resource partitioning and reduce our ability to revegetate rangelands by conventional means.

Key words: Centaurea solstitialis, Bromus tectorum, alien winter annuals, resource allocation and partitioning.

The loss of native perennial vegetation on North American rangelands has been accompanied by invasions of aggressive alien annual weeds. The grassland steppe of the Pacific Northwest, once dominated by native perennial grasses (e.g. bluebunch wheatgrass (Pseudoroegneria spicata [Pursh.] Scribn and Smith)), now contain extensive areas dominated by annual grasses (e.g. cheatgrass (Bromus tectorum L.)) (Mack 1981).

Cheatgrass, a winter annual that matures early in the growing season, arrived from Eurasia well adapted to arid and semi-arid habitats, and expanded its range to include most grasslands in the Intermountain West (Mack 1981, Morrow and Stahlman 1984).

\footnotetext{
Research was funded by the National Park Service Grant CA 9000800006-13 Authors wish to thank Drs. R.F. Miller and S.R. Radosevich for advice regarding research methods. Published as Oregon Agr. Exp. Sta. Tech. Paper No. 10295.

Manuscript accepted 9 April 1994.
}

Much of the success of cheatgrass has been attributed to rapid germination and growth (Hulbert 1955, Harris 1967, Svejcar 1990, Aguirre and Johnson 1991) at low soil temperatures and rather low water availability (Harris 1967, Aguirre and Johnson 1991, Johnson and Aguirre 1991).

Ecologists are concerned that these annual grass communities are in jeopardy of site occupation by noxious Eurasian weeds, such as yellow starthistle (Centaurea solstitialis L.) (Roché and Roché 1988, Callihan et al. 1989, Harris 1989, Hironaka 1989). Currently yellow starthistle is spreading onto grasslands in Washington and Idaho at an estimated 7,800 and 2,800 hectares per year, respectively (Talbott 1987, Callihan et al. 1989). Hironaka (1989) proposed that the sequence of species replacement among winter annuals in the Pacific Northwest would be from early maturing species to later maturing ones. In this scenario, cheatgrass would be replaced by the later maturing medusahead (Taeniatherum asperum Nevski) or yellow starthistle.

Knowledge that improves the management of plant community dynamics will improve our ability to revegetate degraded rangelands (Rosenberg and Freedman 1984, Lukan 1990). Investigations aimed at plant-plant interactions and the relationships which affect dominance, community dynamics, and plant establishment are critical to the development of these successional management systems (MacMahon 1987, Allen 1988, Call and Roundy 1991, Pyke and Archer 1991).

This study was conducted to develop an initial understanding of cheatgrass-yellow starthistle interactions. We used addition series methodology to quantify the effects of interference between cheatgrass and yellow starthistle seedlings, and compare the growth of isolated individuals of these species.

\section{Materials and Methods}

\section{Interference}

Monocultures and mixtures of cheatgrass and yellow starthistle seedlings were grown to assess interaction between the 2 species. Densities of cheatgrass and yellow starthistle were arranged to provide an addition series (Spitters 1983, Radosevich 1987). The cheatgrass:yellow starthistle densities were 10:10, 10:100, 10:1,000, $10: 10,000,100: 10,100: 100,100: 1,000,100: 10,000,1,000: 10$, $1,000: 100,1,000: 1,000,1,000: 10,000,10,000: 10,10,000: 100$, $10,000: 1,000,10,000: 10,000$ plants $\mathrm{m}^{-2}$.

Seeds of cheatgrass and yellow starthistle were sown in $1,824 \mathrm{~mm}^{2}$ (surface area) $\times 400 \mathrm{~mm}$ (depth) polyvinyl chloride tubes (split vertically and taped to a facilitate root removal). Tubes were filled with sterilized Walla Walla silt loam (coarse-silty, mixed, mesic Typic 
Haploxeroll; A horizon) soil. Moisture was added to the soil and allowed to equilibrate to field capacity. No additional watering took place during the study. Seeds were broadcast then manually arranged until a uniform seed distribution was achieved. A small amount $(<2$ mm depth) of dry soil was used to cover the seeds. Tubes were arranged in a randomized-complete-block design with 4 replications and 16 tubes per block in an environmental chamber $\left(10^{\circ} \mathrm{C}, 12\right.$-hour daylength, $500 \mathrm{uE} \mathrm{m} \mathrm{mec}^{-1}$ spectral light). Plants were harvested 37 days after planting.

Sampling involved manually rinsing soil from roots and measuring primary root penetration. Five individual root systems for each species (2 root systems at lowest density) were extracted from each tube, separated from shoots, divided into upper $(0-200 \mathrm{~mm})$ and lower $(>200 \mathrm{~mm}$ ) portions, measured for total length $(\mathrm{cm})$ using a root length scanner (Comair Corp., Melbourne, Australia), and then dried to a constant weight ( 48 hours, $60^{\circ} \mathrm{C}$ ) and weighted $(\mathrm{mg})$. Leaf material was scanned for surface area $\left(\mathrm{cm}^{2}\right)$ (Licor-3100 with conveyor belt, LI-COR, Inc., Lincoln, Neb.), dried to a constant weight (48 hours, $60^{\circ} \mathrm{C}$ ) and weighted $(\mathrm{mg})$.

Addition series data were incorporated into multiple linear stepwise regression models (least squares) using SPSSPC+ procedures (SPSS., Chicago, Ill.) of the form:

$$
\begin{aligned}
& V_{c}=B_{c o}+B_{c c} \log N_{c}+B_{c y} \log N_{y} \\
& V_{y}=B_{y o}+B_{y y} \log N_{y}+B_{y c} \log N_{c}
\end{aligned}
$$

where $V_{c}$ and $V_{y}$ were the average per plant growth response for cheatgrass and starthistle, respectively, and $N_{c}$ and $N_{y}$ were their density. Regression coefficients $B_{c o}$ and $B_{\text {yo }}$ estimate the maximum response of each variable for an isolated individual. Negative and/or nonsignificant intercepts are reported. They are considered to be estimates of values outside the range of the regression plane (Spitters 1983, Rejmanek et al. 1989), or random errors (Pantone and Baker 1991).

The regression coefficients $B_{c c}$ and $B_{y y}$ estimate intraspecific interaction, and $B_{c y}$ and $B_{y c}$ estimate interspecific interation. The ratios $B_{c c}: B_{c y}$ and $B_{y y}: B_{y c}$ determine the relative influence of each species on the variable response. For example, a $B_{c c}: B_{c y}$ ratio of 2 suggests that cheatgrass has twice the influence upon itself in determining the variable response when compared to yellow starthistle. Zero was used for all non-significant coefficients in the regression model, and a constant of 0.0001 was used for ratio calculations (Roush 1988).

The $\left[\mathrm{B}_{\mathrm{cc}} / \mathrm{B}_{\mathrm{cy}}: \mathrm{B}_{\mathrm{yc}} / \mathrm{B}_{\mathrm{yy}}\right]$ double ratio was used to determine the partitioning of resources between species (Spitters 1983, Connolly 1986 , Joliffe 1988). Deviations from unity indicate increased resource partitioning (niche separation). The coefficient of determination $\left(R^{2}\right)$ values were calculated to indicate the proportion of the variability associated with the dependent variable $\left(\mathrm{V}_{\mathrm{c}}\right.$ or $\left.\mathrm{V}_{\mathrm{y}}\right)$ that was accounted for by plant density $\left(\mathrm{N}_{\mathrm{c}}\right.$ and $\left.\mathrm{N}_{\mathrm{y}}\right)$.

Scatterplots of the residuals vs. standardized predicted values were used to determine the homogeneity of variances and the degree of model fit. The $t$-tests $(P \leq 0.05)$ were used to determine significance of regression coefficients.

\section{Individual Growth of Isolated Plants}

Seeds of cheatgrass and yellow starthistle wcre pregerminated and 4 seedlings were transplanted into polyvinyl chloride tubes for each of 10 harvest dates ( 46 days duration, 4 days harvest interval initiated on day 10). Tube surface area was increased with harvest date to insure minimal restriction of root growth (Table 1). Tube length was a constant $800 \mathrm{~mm}$. Tubes were prepared following procedures described in the interference study. Tubes were arranged in a randomized-complete-block design with 5 replications and 10 tubes of
Table 1. Surface area of PVC tubes' at each harvest.

\begin{tabular}{lc}
\hline $\begin{array}{l}\text { Time from } \\
\text { planting }\end{array}$ & $\begin{array}{c}\text { Tube surface } \\
\text { area }\end{array}$ \\
\hline Days & $--\left(\mathrm{mm}^{2}\right)---$ \\
10 & 50.6 \\
14 & 50.6 \\
18 & 202.7 \\
22 & 202.7 \\
26 & 456.0 \\
30 & 810.7 \\
34 & $1,266.7$ \\
38 & $1,824.1$ \\
42 & $1,824.1$ \\
46 & $1,824.1$ \\
\hline
\end{tabular}

Tube length was $800 \mathrm{~mm}$.

each species per block, and placed into an environmental chamber $\left(10^{\circ} \mathrm{C}, 12\right.$-hours daylength, $500 \mathrm{uE} \mathrm{m}^{-2} \mathrm{sec}^{-1}$ spectral light). Plants were transplanted on day 1 of the experiment and thinned to a single individual on day 5. Sampling procedures followed those described for the interference study, with the exception that upper and lower root portions were not separated. Data were analyzed using ANOVA (SPSS., Chicago, Ill.); Fisher's protected L.S.D. $(P \leq 0.05)$ mean comparisons are presented (Peterson 1985).

\section{Results}

\section{Interference}

Intraspecific interference was more important than interspecific interference for the prediction of plant weight (Tables 2 and 3). The influence of cheatgrass density on total cheatgrass weight was 2 times greater than the influence of yellow starthistle density. Similarly, yellow starthistle density was twice as important as cheatgrass density in the prediction of total yellow starthistle weight. Shoot weight and leaf area (data not shown) had a similar interference pattern (Tables 2 and 3). In both cases, cheatgrass density was about 1.5 times more important than yellow starthistle density in the prediction of cheatgrass response, and yellow starthistle density was

Table 2. Multiple regression analysis' for the prediction of cheatgrass total plant weight (mg), shoot weight, and root weight using plant densities. $^{2}$

\begin{tabular}{lccccc}
\hline \hline $\begin{array}{l}\text { Dependent } \\
\text { variable }\end{array}$ & $\mathrm{B}_{\mathrm{co}}$ & $\mathrm{B}_{\mathrm{cc}}$ & $\mathrm{B}_{\mathrm{cy}}$ & $\mathrm{B}_{\mathrm{cc}} / \mathrm{B}_{\mathrm{cy}}$ & $R^{2}$ \\
\hline Total plant & 41.82 & -6.26 & -3.07 & 2.04 & 0.69 \\
weight (mg) & $(3.01)$ & $(0.82)$ & $(0.60)$ & & \\
Shoot weight (mg) & 28.49 & -4.07 & -2.90 & 1.40 & 0.58 \\
& $(2.60)$ & $(0.72)$ & $(0.52)$ & & \\
Root weight (mg) & 12.96 & -2.19 & 0 & $\infty$ & 0.56 \\
& $(0.89)$ & $(0.28)$ & $(\mathrm{NS})$ & & \\
Upper root & 12.73 & -2.24 & -0.44 & 5.08 & 0.71 \\
weight (mg) & $(0.80)$ & $(0.22)$ & $(0.16)$ & &
\end{tabular}

(0-200 mm)

Lower root

weight (mg)

No significant variables

$(>200 \mathrm{~mm})$

$\mathrm{V}_{\mathrm{c}}=\mathrm{B}_{\mathrm{co}}+\mathrm{B}_{\mathrm{cc}} \log \mathrm{N}_{\mathrm{c}}+\mathrm{B}_{\mathrm{cy}} \log \mathrm{N}_{\mathrm{y}}$
'The intercept $\mathrm{B}_{\mathrm{co}}$ estimated the weight of an isolated cheatgrass seedling. Intraspecific interference for cheatgrass is measured by the regression coefficient $B_{c c}$ and interspecific interfence with yellow starthistle by $B_{c y}$ Numbers in parentheses are standard errors for coefficients significantly different from zero. 
Table 3. Multiple regression analysis' for the prediction of yellow starthistle total plant weight (mg), shoot weight, and root weight using plant densities.

\begin{tabular}{lccccc}
\hline \hline $\begin{array}{l}\text { Dependent } \\
\text { variable }\end{array}$ & $\mathrm{B}_{\mathrm{yo}}$ & $\mathrm{B}_{\mathrm{yy}}$ & $\mathrm{B}_{\mathrm{yc}}$ & $\mathrm{B}_{\mathrm{yy}} / \mathrm{B}_{\mathrm{yc}}$ & $R^{2}$ \\
\hline Total plant & 34.56 & -5.30 & -2.69 & 1.97 & 0.62 \\
weight (mg) & $(2.69)$ & $(0.75)$ & $(0.55)$ & & \\
Shoot weight (mg) & 25.45 & -4.27 & -2.00 & 2.14 & 0.58 \\
& $(2.33)$ & $(0.65)$ & $(0.47)$ & & \\
Root weight (mg) & 9.11 & -1.03 & -0.69 & 1.49 & 0.55 \\
& $(0.67)$ & $(0.19)$ & $(1.37)$ & & \\
Upper root & 7.29 & -0.89 & -0.65 & 1.37 & 0.56 \\
weight (mg) & $(0.60)$ & $(0.17)$ & $(0.12)$ & &
\end{tabular}

$(0-200 \mathrm{~mm})$

Lower root

weight (mg)

No Significant Variables

$(>200 \mathrm{~mm})$

$\mathrm{V}_{\mathrm{y}}=\mathrm{B}_{\mathrm{yo}}+\mathrm{B}_{\mathrm{yy}} \log \mathrm{N}_{\mathrm{y}}+\mathrm{B}_{\mathrm{yc}} \log \mathrm{N}$

${ }^{2}$ The intercepl $B_{y o}$ estimated the weight of an isolated yellow starthistle seedling. Intraspecific interference for yellow starthistle is measured by $B_{y y}$ and interspecific interference with cheatgrass by $\mathrm{B}_{\mathrm{yc}}$. Numbers in parentheses are standard errors for coefficients significantly different from zero.

about twice as important as cheatgrass density in predicting yellow starthistle response.

Increasing plant densities were associated with decreasing root weight for both species in the upper portion of the soil profile (Tables 2 and 3). Cheatgrass density had 5 times the influence of yellow starthistle density on cheatgrass root weight $(0-200 \mathrm{~mm})$. In contrast, yellow starthistle density was 1.37 times greater than cheatgrass density in influencing yellow starthistle root weight $(0-200 \mathrm{~mm})$. At soil depths below $200 \mathrm{~mm}$, root weight was not associated with plant density for either species.

The prediction of cheatgrass root length suggests that intraspecific interference was greatest in the upper rooting zone (3.97) (Table 4).

Table 4. Multiple regression analysis' for the prediction of cheatgrass and yellow starthistie on the total root length $(\mathrm{cm})$, upper root length, and lower root length using plant densities. ${ }^{2}$

\begin{tabular}{|c|c|c|c|c|c|}
\hline $\begin{array}{l}\text { Dependent } \\
\text { variable }\end{array}$ & $\mathbf{B}_{\text {co }}$ & $\mathrm{B}_{\mathrm{cc}}$ & $\mathrm{B}_{\mathrm{cy}}$ & $\mathrm{B}_{c c} / \mathrm{B}_{\mathrm{cy}}$ & $R^{2}$ \\
\hline \multicolumn{6}{|l|}{ Cheatgrass } \\
\hline Total root length $(\mathrm{cm})$ & $\begin{array}{l}502.24 \\
(44.47)\end{array}$ & $\begin{array}{l}-47.27 \\
(12.42)\end{array}$ & $\begin{array}{r}-53.92 \\
(9.00)\end{array}$ & 0.88 & 0.53 \\
\hline $\begin{array}{l}\text { Upper root length }(\mathrm{cm}) \\
(0-200 \mathrm{~mm})\end{array}$ & $\begin{array}{l}507.30 \\
(41.45)\end{array}$ & $\begin{array}{l}-89.34 \\
(11.53)\end{array}$ & $\begin{array}{r}-22.52 \\
(8.40)\end{array}$ & 3.97 & 0.60 \\
\hline $\begin{array}{l}\text { Lower root length }(\mathrm{cm}) \\
(>200 \mathrm{~mm})\end{array}$ & $\begin{array}{c}0 \\
\text { (NS) }\end{array}$ & $\begin{array}{c}8.58 \\
(3.55)\end{array}$ & $\begin{array}{c}7.80 \\
(2.63)\end{array}$ & 1.10 & 0.24 \\
\hline $\begin{array}{l}\text { Dependent } \\
\text { variable }\end{array}$ & $\mathbf{B}_{\text {yo }}$ & \multirow[t]{2}{*}{$B_{y y}$} & $\mathrm{~B}_{\mathrm{yc}}$ & $B_{y y} / B_{y c}$ & \multirow[t]{2}{*}{$R^{2}$} \\
\hline ellow starthistle & & & & & \\
\hline Total root length $(\mathrm{cm})$ & $\begin{array}{l}509.02 \\
(55.92)\end{array}$ & $\begin{array}{l}-89.67 \\
(18.02)\end{array}$ & $\begin{array}{c}0 \\
\text { (NS) }\end{array}$ & $\infty$ & 0.35 \\
\hline $\begin{array}{l}\text { Upper root length }(\mathrm{cm}) \\
(0-200 \mathrm{~mm})\end{array}$ & $\begin{array}{c}45.42 \\
(55.29)\end{array}$ & $\begin{array}{l}-72.02 \\
(15.34)\end{array}$ & $\begin{array}{l}-28.27 \\
(11.19)\end{array}$ & 2.54 & 0.39 \\
\hline $\begin{array}{l}\text { Lower root length }(\mathrm{cm}) \\
(>200 \mathrm{~mm})\end{array}$ & $\begin{array}{c}12.45 \\
(21.27)\end{array}$ & $\begin{array}{r}-17.82 \\
(6.87)\end{array}$ & $\begin{array}{c}0 \\
\text { (NS) }\end{array}$ & $\infty$ & 0.13 \\
\hline
\end{tabular}

'Cheatgrass $V_{c}=B_{c o}+B_{c c} \log N_{c}+B_{c y} \log N_{y}$

Yellow starthistle $V_{y}=B_{y o}+B_{y y} \log N_{y}^{y}+B_{y c} \log N_{c}$

The intercepts $B_{c o}$ and $B_{y o}$ estimated the root length of an isolated individual Intraspecific interactions for cheatgrass and yellow starthistle are measured by the $\mathrm{B}_{\mathrm{cc}}$ and $B_{y y}$ regression coefficients, and the interspecific interactions by the $B_{y}$ and $B_{y c}$ regression coefficients, respectively. Numbers in parentheses are standard errors for coefficients significantly different from zero.
Table 5. Multiple regression analysis ${ }^{1}$ for the prediction of cheatgrass and yellow starthistle root:shoot $\left(\mathrm{mg} \mathrm{mg}^{-1}\right)$, root length:leaf surface area $\left(\mathrm{cm} \mathrm{cm}^{-2}\right)$, and lower:upper root length ratios $\left(\mathrm{cm} \mathrm{cm}^{-2}\right)$ using plant densities. ${ }^{2}$

\begin{tabular}{|c|c|c|c|c|c|}
\hline $\begin{array}{l}\text { Dependent } \\
\text { variable }\end{array}$ & $\mathrm{B}_{\mathrm{co}}$ & $\mathbf{B}_{\mathrm{cc}}$ & $\mathbf{B}_{\mathrm{cy}}$ & $\mathrm{B}_{\mathrm{cc}} \mathrm{B}_{\mathrm{cy}}$ & $R^{2}$ \\
\hline \multicolumn{6}{|l|}{ Cheatgrass } \\
\hline Root:shoot & $\begin{array}{c}0 \\
\text { (NS) }\end{array}$ & $\begin{array}{l}0 \\
\text { (NS) }\end{array}$ & $\begin{array}{l}-0.26 \\
(0.06)\end{array}$ & 0 & 0.32 \\
\hline Root length:leaf area & $\begin{array}{c}0 \\
\text { (NS) }\end{array}$ & $\begin{array}{c}49.29 \\
(18.93)\end{array}$ & $\begin{array}{c}0 \\
\text { (NS) }\end{array}$ & $\infty$ & 0.13 \\
\hline Lower:upper & $\begin{array}{l}-0.47 \\
(0.11)\end{array}$ & $\begin{array}{c}0.22 \\
(0.03)\end{array}$ & $\begin{array}{c}0.06 \\
(0.02)\end{array}$ & 3.81 & 0.55 \\
\hline $\begin{array}{l}\text { Dependent } \\
\text { variable }\end{array}$ & B $_{\text {yo }}$ & $\mathrm{B}_{\mathrm{yy}}$ & $\mathrm{B}_{\mathrm{yc}}$ & $B_{y y} / B_{y c}$ & $R^{2}$ \\
\hline $\begin{array}{l}\text { Yellow starthistle } \\
\text { Root:shoot }\end{array}$ & $\begin{array}{c}0 \\
\text { (NS) }\end{array}$ & $\begin{array}{c}0.19 \\
(0.04)\end{array}$ & $\begin{array}{c}0 \\
\text { (NS) }\end{array}$ & $\infty$ & 0.31 \\
\hline Root length:leaf area & $\begin{array}{c}392.40 \\
(207.33)^{3}\end{array}$ & $\begin{array}{c}-109.48 \\
(57.50)^{3}\end{array}$ & $\begin{array}{l}178.29 \\
(42.00)\end{array}$ & -0.61 & 0.33 \\
\hline
\end{tabular}

Lower:upper

No Significant Variables

Cheatgrass $V_{c}=B_{c o}+B_{c c} \log N_{c}+B_{c y} \log N_{x}$
Yellow starthistle $V_{y}=B_{y o}+B_{1 y} \log N_{y}+B_{y c} \log N_{c}$

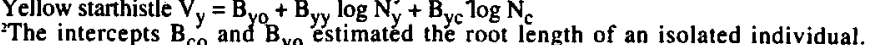
Intraspecific interactions for cheatgrass and yellow starthistle are measured by the $B_{\mathrm{cc}}$ $\vec{T}:-\quad$ terspecific interactions by the $B_{c y}$ and $B_{y c}$ , $\therefore$, sers in parentheses are standard errors for ${ }_{3} \dot{p}=0.06$

Decreasing root length (total and upper) was associated with increased cheatgrass density. Intraspecific interference decreased yellow starthistle root length (Table 4). Cheatgrass density decreased yellow starthistle upper root length.

Increasing cheatgrass density was associated with increases in the cheatgrass root length:leaf area and lower:upper root length ratios (Table 5). However, increasing yellow starthistle density was associated with a decrease in cheatgrass root:shoot ratios. Mean comparisons $(P \leq 0.05)$ of cheatgrass root length:leaf area ratios showed that cheatgrass densities of 10,000 plants $\mathrm{m}^{-2}$ were necessary to achieve a significant ratio increase (data not shown).

Yellow starthistle root length:leaf area ratio was influenced by intraspecific and interspecific interference (Table 5). Increases in yellow starthistle density decreased the root length:leaf area ratio of yellow starthistle. Whereas, increasing cheatgrass density increased the yellow starthistle root length:leaf area ratio. Lower:upper root length ratios for yellow starthistle were not associated with either yellow starthistle or cheatgrass density.

The increases in root:shoot and lower:upper root ratios described above were associated with detectable increases in soil depth penetration. The model fit for predicting soil depth penetration was poor. The effect of density on soil depth penetration by yellow starthistle suggests a trend of decreasing penetration with increasing yellow

Table 6. Double ratio $\left(\mathrm{B}_{c c} / \mathrm{B}_{c y}: \mathrm{B}_{\mathrm{y}} / \mathrm{B}_{\mathrm{yy}}\right)$ assessing the resource partitioning based on cheatgrass and yellow starthistle weight (mg).'

\begin{tabular}{lc}
\hline Dependent & $\mathbf{B}_{\mathrm{cc}} / \mathbf{B}_{\mathrm{cy}}: \mathbf{B}_{\mathrm{yc}} / \mathbf{B}_{\mathrm{yy}}$ \\
variable & 4.86 \\
\hline Total plant weight & 3.10 \\
Total shoot weight & $\infty$ \\
Total root weight $(0-400 \mathrm{~mm})$ & 6.98 \\
Upper root weight $(0-200 \mathrm{~mm})$ &
\end{tabular}

'Ratio other unity indicate occurrence of resource partitioning. 
Table 7. Mean shoot weight, root weight, leaf area, total root length, and root length/leaf area ratio for cheatgrass and yellow starthistle grown in isolation.

\begin{tabular}{lccccc}
\hline $\begin{array}{l}\text { Days } \\
\text { from } \\
\text { planting }\end{array}$ & $\begin{array}{c}\text { Shoot } \\
\text { weight/ } \\
\text { plant }\end{array}$ & $\begin{array}{c}\text { Root } \\
\text { weight/ } \\
\text { plant }\end{array}$ & $\begin{array}{c}\text { Leaf } \\
\text { area/ } \\
\text { plant }\end{array}$ & $\begin{array}{c}\text { Total root } \\
\text { length/ } \\
\text { plant }\end{array}$ & $\begin{array}{c}\text { Root length: } \\
\text { leaf area } \\
\text { ratio }\end{array}$ \\
\hline & $-\ldots-(\mathrm{mg})-\ldots-$ & $\left(\mathrm{cm}^{2}\right)$ & $(\mathrm{cm})$ & $\left(\mathrm{cm} \mathrm{cm}^{-2}\right)$
\end{tabular}

\begin{tabular}{lrrrrr}
10 & 1.12 & 0.36 & 0.27 & 41 & 164 \\
14 & 2.43 & 1.24 & 0.55 & 131 & 232 \\
18 & 3.59 & 2.62 & 0.87 & 257 & 299 \\
22 & 7.85 & 3.15 & 1.61 & 317 & 203 \\
26 & 13.19 & 5.46 & 3.23 & 437 & 140 \\
30 & 27.65 & 12.85 & 5.77 & 970 & 177 \\
34 & 45.00 & 22.85 & 9.11 & 1,233 & 133 \\
38 & 107.48 & 42.00 & 16.64 & 1,652 & 113 \\
42 & 143.38 & 56.93 & 22.25 & 2,017 & 94 \\
46 & 327.71 & 137.81 & 41.34 & 3,858 & 95 \\
LSD(0.05) & 53.36 & 13.22 & 4.51 & 363 & $*$ \\
\hline
\end{tabular}

starthistle density (Soil depth penetration by starthistle $=420.9-9.71$ $\log \mathrm{N}_{\mathrm{y}} ; \mathrm{R}^{2}=0.10$ ). In contrast, soil depth penetration by cheatgrass increased with density increases in either species (Soil depth penetration by cheatgrass $=219.53+23.51 \log \mathrm{N}_{\mathrm{c}}+16.31 \log \mathrm{N}_{\mathrm{y}} ; \mathrm{R}_{2}=$ 0.20 ).

Coefficient of determination $\left(R^{2}\right)$ values ranged from 0.56 to 0.71 for each dependent variable involving weight (Tables 2 and 3). The double ratio $\left[\mathrm{B}_{\mathrm{cc}} / \mathrm{B}_{\mathrm{cy}}: \mathrm{B}_{\mathrm{yc}} / \mathrm{B}_{\mathrm{yy}}\right]$ analysis indicates that resource partitioning occurred with respect to total plant, total shoot, total root, and upper root weight (Table 6). Ratio values ranged from 3.10 to infinity.

\section{Individual Growth of Isolated Plants}

Shoot weight, root weight, leaf area, and total root length were similar for both species (Table 7). At each harvest date t-test $(P \leq 0.05)$ failed to show differences between species. After 34 days from planting, each parameter increased as days from planting increased, with the exception of the root length:leaf area ratio which tended to decline throughout the 46-day experiment.

Yellow starthistle had a lower initial root:shoot ratio $(0.16)$ than did cheatgrass $(0.55)$ (Table 8 ). Individual $t$-tests at other harvest dates failed to reveal significant differences. Yellow starthistle roots grew deeper into the soil than cheatgrass after 22 days, and penetrated almost twice as deep as cheatgrass by 46 days.

\section{Discussion}

Cheatgrass and yellow starthistle seedling populations are influenced primarily by intraspecific rather that interspecific interference. The ecological importance of intraspecific interference is associated with the process of self-thinning and being a strong competitor (Aarssen 1983, Pyke and Archer 1991). Palmbald (1968) studied intraspecific density effects upon several weeds, including cheatgrass. He concluded that cheatgrass used the process of self-thinning along with plasticity to ensure a reliable seed source. The ability of cheatgrass seedlings to suppress perennial grass seedlings has been attributed to rapid growth rate and the development of a root system adapted to declining soil moisture profiles (Evans 1961, Harris 1967, Svejcar 1990, Aquirre and Johnson 1991, Johnson and Aquirre 1991). Similarly, yellow starthistle was found to be a stronger competitor than perennial pubescent wheatgrass (Thinopyrum intermedi-
Table 8. Root:shoot ratios and soil depth penetration for cheatgrass and yellow starthistle grown in isolation. ${ }^{1}$

\begin{tabular}{|c|c|c|c|c|}
\hline \multirow{2}{*}{$\begin{array}{l}\text { Days } \\
\text { from } \\
\text { planting }\end{array}$} & \multicolumn{2}{|c|}{ Root:shoot ratio } & \multicolumn{2}{|c|}{ Soil depth penetration } \\
\hline & Cheatgrass & Starthistle & Cheatgrass & Starthistle \\
\hline & \multicolumn{2}{|c|}{$\ldots-\ldots$} & \multicolumn{2}{|c|}{$\ldots-(\mathrm{mm})-\ldots$} \\
\hline 10 & 0.55 & 0.16 & 81 & 93 \\
\hline 14 & 0.65 & 0.51 & 120 & 150 \\
\hline 18 & 0.85 & 0.69 & 114 & 184 \\
\hline 22 & 0.38 & 0.57 & 150 & 260 \\
\hline 26 & 0.38 & 0.50 & 166 & 325 \\
\hline 30 & 0.52 & 0.52 & 209 & 427 \\
\hline 34 & 0.54 & 0.42 & 265 & 521 \\
\hline 38 & 0.47 & 0.32 & 335 & 567 \\
\hline 42 & 0.50 & 0.34 & 382 & 715 \\
\hline \multirow[t]{2}{*}{46} & 0.43 & 0.63 & 404 & 767 \\
\hline & \multicolumn{2}{|c|}{$\operatorname{LSD}(0.05)=0.22$} & \multicolumn{2}{|c|}{$\operatorname{LSD}(0.05)=88$} \\
\hline
\end{tabular}

um spp. barbulatum (Schur) Bark, W. \& D. R. Dewey) (Prather and Callihan 1991). Yellow starthistle possesses seedling growth rates similar to cheatgrass in terms of root and shoot weight, leaf area, and root length.

Our results suggest that cheatgrass and yellow starthistle seedlings reduce interspecific interaction by partitioning resources, and that the mechanism for this partitioning is related to rooting depth (Table 8). Functional niche differentiation between plant populations and the ability of species coexistence based on rooting depth has a strong theoretical basis (Berendse 1979, Berendse 1981, Berendse 1982). Yellow starthistle roots grew to a greater soil depth than cheatgrass roots, suggesting vertical resources partitioning (e.g. soil moisture) between populations. Furthermore, yellow starthistle populations typically mature later than cheatgrass (Sheley et al. 1993, Sheley and Larson 1994). We believe that interspecific interference between cheatgrass and yellow starthistle is limited by vertical and temporal resource partitioning.

Density related plasticity was associated with increased root resource allocation. Yellow starthistle root:shoot ratio increased with increasing densities. Similar trends have been reported for other species (Berendse 1981) and for cheatgrass (Dakheel 1986). Increasing cheatgrass densities were also associated with increased cheatgrass and yellow starthistle root length:leaf area ratios. Resource allocation to lower root portions $(>200 \mathrm{~mm})$ increased in cheatgrass as densities increased. This characteristic should serve to stabilize populations and reduce the number of non-reproducing individuals during drought conditions.

Knowledge of resource partitioning can enhance efforts to revegetate degraded rangelands (Pyke and Archer 1991). Selection of plants having contrasting above and below ground allocation patterns, in particular at seedling and juvenile stages, augment resource partitioning, and the probability of niche separation. The invasion by yellow starthistle into cheatgrass dominated rangeland also represents resource partitioning. However, in this case, resource partitioning in conjunction with population plasticity will likely decrease our ability to revegetate rangelands by conventional means.

\section{Literature Cited}

Aarssen, L.W. 1983. Ecological combining ability and competitive combining ability in plants: Toward a general evolutionary theory of coexistence in systems of competition. Amer.. Natur. 122:707-731. 
Aguirre, L., and D.A. Johnson. 1991. Root morphological development in relation to shoot growth in seedlings of four range grasses. J. Range Manage. 44:341-346.

Allen, M.F. 1988. Belowground structure: A key to reconstructing a productive arid ecosystem, p. 113-135. In: E.B. Allen (ed.), The reconstruction of disturbed arid lands: An ecological approach. Westview Press, Boulder, Colo.

Berendse, F. 1979. Competition between plant populations with different rooting depths. Oecologia 48:19-26.

Berendse, F. 1981. Competition between plant populations with different rooting depths. II. Pot Experiments. Oecologia 48:334-341.

Berendse, F. 1982. Competition between plant populations with different rooting depths. III. Field Experiments. Oecologia 53:50-53.

Call, C.A., and R.A. Roundy. 1991. Perspectives and processes in revegetation of arid and semiarid rangelands. J. Range. Manage. 44:543-549.

Callihan, R.H., F.E. Northam, J.B. Johnson, E.L. Michalson, and T.S. Prather. 1989. Yellow starthistle biology and management in pasture and rangeland. University of Idaho, CIS No. 634. Moscow, Ida.

Connolly, J. 1986. On difficulties with replacement series methodology in mixture experiments. J. Appl. Ecol. 23:125-127.

Dakheel-Al, A.J. 1986. Interference, growth and physiological response of downy brome (Bromus tectorum) and medusahead (Elymus caput-medusae L.). Ph.D. Thesis, University of California, Davis, Calif.

Evans, R.A. 1961. Effects of different densities of downy brome (Bromus tectorum) on growth and survival of crested wheatgrass (Agropyron desertorum) in the greenhouse. Weeds. 9:216-223.

Harris, G.A. 1967. Some competitive relationships between Agropyron spicatum and Bromus tectorum. Ecol. Monogr. 37:89-111.

Harris, G.A. 1989. Cheatgrass: Invasion potential and managerial implications, p. 5-9. In: Roché, B.F., Jr., and C.T. Roché (eds.), Range weeds revisited. Coop. Ext. W.S.U. Misc. 0143. Pullman, Wash.

Hironaka, M. 1989. Range ecology as the basis for vegetation management, p. 11-14. In: Roché, B.F., Jr., and C.T. Roché (eds.), Range weeds revisited. Coop. Ext. W.S.U. Misc. 0143. Pullman, Wash.

Hulbert, L.C. 1955. Ecological studies of Bromus tectorum and other annual bromegrasses Ecol. Mongr. 25:181-213.

Johnson, D.A., and L. Aguirre. 1991. Effect of water on morphological development in seedlings of three range grasses: Root branching patterns. J. Range Manage. 44:355-360.

Jolliffe, P.A. 1988. Evaluating the effects of competitive interference on plant performance. J. Theor. Biol. 130:447-459.

Lukan, J.O. 1990. Directing ecological succession. Chapman and Hall. London.

Mack, R.N. 1981. Invasion of Bromus tectorum L. into western North America: an ecological chronicle. Agro-ecosystems 7:145-165.

MacMahon, J.A. 1987. Disturbed lands and ecological theory: an essay about a mutualistic association, p. 221-237. In: W.R. Jordan, M.E. Gilpin, and J.D. Aber (cds.), Restoration ecology: A synthetic approach to ecological research. Cambridge Univ. Press. New York, N.Y.

Morrow, L.A., and P.W. Stahlman. 1984. The history and distribution of downy brome (Bromus tectorum) in North America. Weed Sci. 32:2-6.

Palmblad, I.G. 1968. Competition in experimental populations of weeds with emphasis on the regulation of population size. Ecology 49:26-34.

Pantone, D.J., and J.B. Baker. 1991. Reciprocal yield analysis of red rice (Oryza sativa) competition in cultivated rice. Weed Sci. 39:42-47.

Peterson, R.G. 1985. Design and analysis of experiments. Marcel Dekker, Inc. New York, N.Y.

Prather, T.S., and R.H. Callihan. 1991. Interference between yellow starthistle and pubescent wheatgrass during grass establishment. J. Range Manage. 44:443-446.

Pyke, D.A., and S. Archer. 1991. Plant-plant interactions affecting plant establishment and persistence on revegetated rangeland. J. Range. Manage. 44:550-557.

Radosevich, S.R. 1987. Methods to study interactions among crops and weeds. Weed Technol. 1:190-198.

Rejmanek, M., G.R. Robinson, and E. Rejmankova. 1989. Weed-crop competition: Experimental designs and models for data analysis. Weed Sci. 37:276-284.

Roché, C.T., and B.F. Roché, Jr. 1988. Distribution and amount of four knapweed (Centaurea L.) species in eastern Washington. Northwest Sci.
62:242-251.

Rosenberg, D.B., and Freedman, S.M. 1984. Application of a model of ecological succession to conservation and land-use management. Environ. conservation 11:323-329.

Roush, M.L. 1988. Models of a four-species annual weed community: Growth, competition, and community dynamics. Ph.D. Dissertation, Oregon State University, Corvallis, Ore.

Sheley, R.L., and L.L. Larson. 1994. Comparative life-histories of cheatgrass and yellow starthistle. J. Range Manage. 47:444-450.

Sheley, R.L., L.L. Larson, and D.E. Johnson. 1993. Germination and root dynamics of three range weeds and two forage species. Weed Technol. 7:234-237.

Spitters, C.J.T. 1983. An alternative approach to the analysis of mixed cropping experiments. I. Estimation of competition effects. Netherlands. J. Agr. Sci. 31:1-11.

Svejcar, T.J. 1990. Root length, leaf area, and biomass of crested wheatgrass and cheatgrass seedlings. J. Range. Manage 43:446-448.

Talbott, C.J. 1987. Distribution and ecological amplitude of selected Centaurea species in eastern Washington. M.S. Thesis, Washington State University, Pullman, Wash. 